\title{
Justice and trust as antecedents of careerist orientation
}

\section{Authors:}

\section{Dr. Jonathan R. Crawshaw}

Work and Organisational Psychology Group

Aston Business School

Aston University

Aston Triangle

Birmingham, B4 7ET

Email: j.r.crawshaw2@aston.ac.uk

Tel: +44 (0)1212043130

\section{Biography}

Jonathan Crawshaw holds a $\mathrm{PhD}$ from Aston University. He is currently a Lecturer in HRM at the Work and Organisational Psychology Group, Aston Business School. His main research interests include individual and organisational career management, organisational justice, and workplace ethics. Jonathan Crawshaw is the corresponding author and can be contacted at: j.r.crawshaw2@aston.ac.uk.

\section{Prof. Felix Brodbeck}

Chair of Industrial and Organisational Psychology

Department of Psychology

Ludwig-Maximilians-University Munich.

Leopoldstrasse 13

80802 Munich

E-Mail: brodbeck@psy.lmu.de

Tel: +498921805201

\section{Biography}

Felix Brodbeck is Professor of Industrial and Organisational Psychology at LudwigMaximilians-University in Munich. His main research interests are leadership, group performance, collective information processing, diversity and cross-cultural psychology. 


\title{
Manuscript Title: \\ Justice and trust as antecedents of careerist orientation
}

\begin{abstract}
Purpose - This paper explores the antecedents of careerist orientations to work. Hypotheses are drawn from referent cognitions theory. Firstly it is proposed that trust mediates the relationship between an individual's perceptions of procedural justice and their careerist orientations to work. Secondly, perceptions of distributive justice, regarding the allocation of career development opportunities, will moderate the relationship between trust and careerist orientations to work.

Design/methodology/approach - 325 employees of a large UK financial institution completed a structured questionnaire. Regression analysis (using SPSS version 11) was used to test the presented hypotheses.

Findings - All hypotheses were confirmed. However, the interaction effect observed was different to the one hypothesized. It appears that trust only matters, in terms of the development of careerist orientations to work, when individuals feel that they are receiving equitable career development opportunities.

Research limitations/implications - Much more research is required in different organisational contexts if we are to fully confirm and understand these relationships. However, these findings suggest that employers will only reduce the development of careerist attitudes in their workforce if they ensure the fair distribution of career development opportunities and engender trusting relations through the implementation of fair decision-making procedures.

Originality/value - This paper adds much needed empirical research to the literature on new career realities and careerist orientations to work. Moreover, referent cognitions theory is presented as a new theoretical framework for understanding the cognitive processes involved in an individual's development of careerist attitudes.
\end{abstract}

Keywords - Careerist orientations to work, careerism, career development, trust, distributive justice, procedural justice.

Paper type - Research paper 


\section{Introduction}

There is a general consensus within the careers literature that for many individuals the nature of their career development, and their experiences of organisational career management practices, may be very different from those of previous generations (for reviews see Arnold, 2001; Newell, 1999; Sullivan et al., 1998). Variously described as post-corporate (Peiperl and Baruch, 1997), boundaryless (Arthur and Rousseau, 1996) or protean (Hall, 1976) careers, for these individuals career progression and advancement may be more fragmented, unpredictable, non-linear and made up of more short-term discreet episodes of employment (Arnold, 2001). Such changes are viewed as reflecting wider changes in the psychological contract, where the psychological contract refers to the perceived mutually agreed reciprocal obligations between employer and employee (see Rousseau, 1995). It is argued that an exchange of long term job security (a 'job for life') and regular advancement opportunities for employee commitment, loyalty and high performance is no longer viable in a context of flexible, post-bureaucratic organisational structures and work practices (Newell, 1999). Instead, a 'new deal' (Herriot and Pemberton, 1997; 1996) is proposed were employers can offer competitive rewards and continuous development of transferable skills in exchange for an employee's flexibility, high performance and citizenship (at least over the short term).

For employers the nature and role of organisational career management practices has therefore changed. No longer are they viewed as the key architects of an individual's career, nurturing their growth from early stages of work through to retirement via effective succession planning and management development programmes (Hall, 1976). Instead they are facilitators, coaches, advisers and enablers for employees' career development and aspirations whether they are going to stay long term within the organisation or not (see Baruch and Peiperl, 2000). For individuals, ownership and responsibility for career management is increasingly theirs, and theirs alone (see Crawshaw, 2006). As employers take a step back from their more traditional paternalistic role, employees must therefore become career entrepreneurs (Arthur, et al., 1995) effectively planning and managing their own long term career aspirations and advancement. If not, they may find their careers stalling, plateauing or even failing entirely very early on in their working lives (see Greenhaus et al., 2000; Stumpf et al., 1983).

A reported (but as yet under-researched) consequence of these changes in ownership and responsibility for careers may be the increasing development of individuals with more careerist orientations to work (Chay and Aryee, 1999; Feldman, 1985). Careerist orientated employees are defined as those that pursue their own career goals at the expense of the goals of their team and/or employing organisation (Feldman and Weitz, 1991). For careerists the link between their own job performance and their job security, continuous career progression and advancement within organisations is broken (Feldman and Weitz, 1991; Feldman, 1985). The careerist believes that in the increasingly competitive internal and external labour markets associated with the new transactional psychological contract described above performance and competence alone may not be enough to secure their career goals and aspirations. Simple loyalty and commitment may not necessarily be rewarded by their employer and thus their job security must be taken into their own hands. In terms of their career development, careerists are therefore thought more likely (than non-careerists) to behave 
instrumentally at work, seeking desired career development opportunities through the implementation of non-performance based strategies, such as politicking, deception, impression management, and presenteeism (Feldman, 1985). In other words, they begin to assume that "market value may be more highly rewarded than value added" (Feldman and Weitz, 1991, p. 238), when it comes to securing access to valued organisational career development opportunities and organisational career management interventions and resources.

Importantly for employers, careerists initiate such career management strategies at the expense of their assigned job roles and responsibilities (Chay and Aryee, 1999; Feldman and Weitz, 1991). Past empirical research highlights as much, reporting significant negative associations between careerist orientations to work and a number of important individual, work and organisation focussed outcomes including, organizational commitment, turnover intentions, job satisfaction and job involvement (e.g. Orpen, 1998; Feldman and Weitz, 1991). Employers therefore face a difficult balancing act in the contemporary post-bureaucratic employment relationship. On the one hand, a committed, flexible and high performing workforce will be essential to if organisations are to survive in an ever more competitive marketplace (Kanter, 1990). On the other, the implications for more self-managed, or protean, careers may be leading to a greater emergence of careerist orientations in their workforce. If employers are going to achieve competitive advantage it is therefore essential that they tackle this key contradiction and dilemma in the employment relationship (Aryee and Chen, 2004).

Unfortunately few studies have investigated the conditions under which careerist orientations to work are more or less likely to develop, thus limiting the theoretical and empirical development of the field. Feldman and Weitz (1991), in their seminal paper, theorize that careerist orientations to work develop when an individual's trust in their employer is lost. A more recent study from Aryee and Chen (2004), of 158 employees of a Chinese household appliance manufacturer in the People's Republic of China, extended further these propositions finding empirical support for trust as a mediator in the relationship between perceptions of distributive and procedural justice and careerist orientations to work. They reported that positive employee perceptions regarding the fairness of their rewards and the procedures used to decide them reduce the development of careerist orientations to work, because they promoted in individuals a high level of trust in their employer. It appears that employers may overcome the difficult challenges of managing the employment relationship and minimise the emergence of a careerist orientated workforce by maintaining or rebuilding trust through the development of fair organisational career management practices. In other words, even when employers may not be able to provide employees with the career development opportunities they desire (perhaps in times of economic hardship and recession), as long as the system and processes are fair, trust should be maintained and careerism suppressed.

It is the authors' view, however, that Aryee and Chen's work is still the only study to have empirically tested for these relationships between organisational justice, trust and careerist orientation. Given the very specific Chinese manufacturing setting for this study it is essential that more research is carried out in new national and employment sector contexts if our confidence in the utility of these findings is to be increased. Moreover, and despite the importance of Aryee and Chen's study, it is also 
not without its limitations. Firstly, general measures of distributive justice and procedural justice were used in this study. In other words, employees were asked to rate their overall perceptions of fairness regarding their employer, with some apparent focus on issues of pay and reward. Although useful, the present authors feel that the literature would be benefited by research that focuses on issues of distributive justice and procedural justice in relation to employees' experiences of career development opportunities and organisational career management practices specifically. It is essential to clarify whether or not it is the fairness of organisational policies and practices directly introduced to influence one's career development that may predict careerist orientation. Secondly, Aryee and Chen present distributive justice and procedural justice as antecedents of trust and careerist orientation within a simple social exchange model. Organisational justice research has, however, long found support for more complex interrelationships between distributive justice, procedural justice and trust (explained in more detail later in the paper) when predicting outcomes (for reviews see Brockner et al., 2001; Cropanzano and Greenberg, 1997). By drawing on referent cognitions theory (Folger, 1987) the present study contributes to the literature by testing for these mediating and moderating effects. The authors feel that this paper contributes to a growing and important body of research that has begun to explore in more detail the roles of justice and trust perceptions in explaining employee evaluations of, and reactions to, their career development opportunities and employers' career management strategies (see Crawshaw, 2006; Aryee and Chen, 2004; Wooten and Cobb, 1999).

\section{Organisational justice and referent cognitions theory (RCT)}

Figure 1 is based on Brockner et al. (2001) and presents a summary of the model tested in this research. Concerns of distributive justice and procedural justice have dominated the organisational justice literature (Colquitt et al., 2001). The earliest justice research focussed on issues of distributive justice, with Adams' (1965) equity theory prominent. In line with Adams, distributive justice refers to an individual's perceptions of fairness in relation to their comparative outcomes from a decisionmaking system (Cropanzano and Greenberg, 1997). According to the principles of distributive justice, therefore, an individual would judge their career development opportunities as fair if they reflected accurately their relative (in comparison to their colleagues) contributions to the organization (e.g. skills, performance, experience, and effort) (see Wooten and Cobb, 1999). For example, distributive justice is upheld when a secondment (or other desired career development opportunity) is given to someone whose performance, experience and skills have merited it.

\section{INSERT FIGURE 1 ABOUT HERE}

Later studies shifted their attentions to concerns of procedural justice, where procedural justice refers to an individual's perceptions of fairness in relation to the organizational procedures followed to reach these decisions. Drawing upon the early research of Thibaut and Walker (1975) and Leventhal (1980), decision-making, regarding the distribution of career development opportunities, that is perceived to be objective, consistent, transparent, ethical, based on accurate data, and allows an 
individual a voice and a chance to challenge the outcome, will be seen as more procedurally fair and just (for a review, see Colquitt et al., 2001).

In contrast to the outcome-focussed nature of distributive justice, perceptions of procedural justice are organization-directed. That is, they reflect an individual's perceptions of fairness in relation to the structures and systems of their employing organization (for a review, see Cropanzano and Greenberg, 1997). It is predicted, therefore, that such justice judgements will have implications for organizationdirected attitudes and behaviours, such as careerist-orientation to work (see Aryee and Chen, 2004). As outlined above, individuals with a careerist orientation to work commonly believe that career advancement will be more likely to be achieved through impression management and deception, rather than formal, transparent, consistent and ethical procedures (Feldman and Weitz, 1991); in other words, under conditions of procedural injustice. In summary the following hypothesis is therefore proposed:

Hypothesis 1: Employee perceptions of procedural justice, regarding the allocation of career development opportunities, will be negatively related to their careerist orientations to work.

\section{Trust as a mediator}

More recent organisational justice research, however, has begun to question the direct main effects of procedural justice perceptions, in particular, focussing on the potential mediating role of trust (see Aryee and Chen, 2004). It is proposed that perceptions of procedural justice matter only because they inform an individual's perceptions of trust in their employer. Specifically, that fair procedures act as either a guide (Aryee et al., 2002) or heuristic (van den Bos et al., 2001; van den Bos et al., 1998) for individual's to make evaluations of trustworthiness in respect of their employer.

This role of trust in the employment relationship has been explained in a number of ways. The earliest research tended to focus on trust as a purely economic concern of employees. Put simply, trust is important because it provides information about the likely benefits (e.g. career development opportunities) to be gained from their current context of employment (Lind and Tyler, 1988). Later research, however, also recognised non-instrumental concerns of trust (Lind and Tyler, 1988). Drawing on social identity theory (see Tajfel and Turner, 1979), authors such as Tyler and Degoey (1996) argued that trust may also provide individuals with identity-relevant information. In other words, being shown trust by one's colleagues and/or employer is important because it provides you with information about your standing within the organization (Tyler and Kramer, 1996). Past research has also shown that effective careers and career management experiences are central to the formation of an individual's self and identity (e.g. Adamson, 1997).

Despite important differences in these two perspectives, in both cases trust is viewed as part of a reciprocal relationship between employer and employee (Tyler and Kramer, 1996). Such reciprocity has been the central tenet of research into the psychological contract (see Rousseau, 1995). Research such as that by Robinson (1996) and Robinson and Morrison (2000) places trust at the heart of concerns of psychological contract breach. They proposed that it is trust that explains, and holds together, this reciprocal relationship. When an individual perceives their employer to 
have reneged on a promise (e.g. developing and initiating fair decision-making processes and procedures), they reciprocate by removing/reducing their efforts and/or expertise (or exiting the organisation entirely) because they have lost trust in them (see Aryee et al., 2002). In line with this earlier research (see also Aryee and Chen, 2004) the present study predicts that the negative relationship between perceptions of procedural justice and careerism will be explained by an individual's trust in management. In other words, positive perceptions of procedural justice will reduce careerist orientations because high levels of procedural justice help maintain trust in the employment relationship. The following hypothesis is proposed:

Hypothesis 2: Employee perceptions of trust in management are negatively related to their careerist orientations to work, and will fully mediate the relationship between their perceptions of procedural justice and careerist orientations.

\section{When trust matters more - referent cognitions theory (RCT)}

An important limitation of this research is that it has largely ignored the context in which trust is engendered, with very few studies having explored the existence of moderators of the relationship between trust and important work and organisation focussed attitudes and behaviours such as careerist orientation (Brockner and Siegel, 1996). Distributive justice is, however, one potential moderator of this relationship that has received some attention in the organisational justice literatures (Brockner et al., 1997; Brockner and Siegel, 1996). Drawing on RCT, past research has shown that trust in management may become more strongly related to important work and organization-directed outcomes under conditions of low (rather than high) distributive justice (for a review, see Brockner and Wiesenfeld, 1996). When individuals feel that desired rewards or resources are being distributed unfairly (low distributive justice), they initiate cognitive sense-making processes in an attempt to understand why and, perhaps more importantly, what their outcomes could and should have been under different circumstances (Folger, 1987). In answering these questions RCT argues that individuals are in fact seeking information regarding the trustworthiness of the decision-making system (that is, the employer). Conversely, when distributive justice perceptions are high, individuals feel no need to further explore the reasons for this decision as their treatment has been fair (Folger, 1987). The trustworthiness of management therefore matters more to people under conditions of low, rather than high, distributive justice.

If they subsequently decide that their trust in management is high (at least in part because decision-making procedures are subsequently viewed as fair - or high procedural justice) this may help 'buffer' the potential negative implications for work related attitudes and behaviours associated with perceptions of distributive injustice. Regardless of the perceived unfairness of their current outcomes, high levels of trust in management may therefore convince an individual of either their long term gain from that organization (self-interest), or their continuing social standing in their work group (group-value), thus reducing the negative implications for organization-directed outcomes (see Tyler and Lind, 1992; Tyler, 1989).

The authors' propose the same effects within the context of this study, that the negative relationship between trust in management and careerist orientations to work is moderated by their perceptions of distributive justice regarding their career 
development opportunities. If an individual doesn't receive a promotion, secondment, access to a mentor or development centre (or any other desirable career development opportunity) that they think they deserve (low distributive justice), it is argued that this will trigger further sense-making of this decision. They will subsequently focus on collecting information on the trustworthiness of the decision-making system. If the system is found to be trustworthy (because the procedures followed were deemed fair) this should 'buffer' the potential negative implications for careerist-orientations to work. The following hypothesis is therefore proposed:

Hypothesis 3: The negative relationship between an individual's perceptions of trust in management and careerist orientations to work will be stronger under conditions of low (rather than high) perceived distributive justice regarding their career development opportunities.

\section{Research Methods}

\section{Organisational context}

FinanceCo is a large UK high street financial provider employing over 15,000 employees across around 700 retail branches, three regional call centres and a central head office site. FinanceCo grew out of the plethora of mergers, acquisitions, demergers and restructures that dominated and defined the financial services sector throughout the later part of the twentieth century. At the time of this study FinanceCo reports to have approximately 10 million commercial and personal customers and boasts some form of relationship with about one in four of all UK households. FinanceCo was selected for this study because analysis of company documents and other related literatures suggested that management placed a considerable emphasis on the development and implementation of sophisticated and effective career development interventions, extolling much of the career management rhetoric of current Chartered Institute of Personnel and Development (CIPD) 'best practice' prescriptions (see Harrison, 2002). FinanceCo's mission is to ensure that all employees are, "encouraged to develop... onwards and upwards" maintaining fair treatment and equality for all (FinanceCo website). The most recent (at the time of this study) Chief Executives Review presents some evidence that these objectives were in fact being met stating that, "... having continued to invest in our employees, we moved up to $18^{\text {th }}$ in the list of the ' 100 Best Companies to Work For', published in The Sunday Times... an achievement that was particularly satisfying because $80 \%$ of our total score was based on what our employees said about what it is like to work for FinanceCo" (Annual Report and Accounts, 2004: p. 5). By emphasising the importance of organisational career management (OCM) policies and developing and implementing sophisticated OCM practices to support them, FinanceCo provides an excellent environment to test hypotheses focussed on understanding the relationships between employee perceptions of justice, regarding OCM practices, and careerist orientations to work.

\section{Participants}

Access to FinanceCo was negotiated through a senior member of the HR team. This process involved ongoing telephone and email conversations as well as a number of face-to-face meetings with this contact. Access was granted on condition of complete 
anonymity and confidentiality for all participants as well as the organisation. Regular reports and feedback to the organisation on the study's findings and analysis was also agreed between the researchers and the organisation. One thousand one hundred employees were selected (by the organisation) from the wider organisational population, by random stratified sampling techniques, to take part in a questionnaire survey. The aim was to generate a representative sample of the workforce across gender, ethnic origin, hierarchical position, contract type, employment status and department/function. The questionnaires, along with prepaid return addressed envelopes, were distributed by the author via the internal mail system and returned anonymously to the authors' institution. 325 questionnaires were fully completed and returned which gave a final usable response rate of $30 \%$. Of these respondents, $41.5 \%$ were in management positions, $68.3 \%$ were female, $92.6 \%$ were of white UK ethnic origin and their average age and length of service were 34.5 years and 8.8 years respectively. These figures reflected closely the demographic profile of the wider employee population $(\mathrm{N}=1100)$ and thus promoted confidence in the representative nature of this sample.

\section{Measures}

Employee perceptions of distributive justice regarding their career development opportunities were measured using a five item scale developed by Colquitt (2001). Participants were asked to respond, along a 5-point Likert scale (from a very little extent [1] to a very great extent[5]), to the following questions, "Do your career development opportunities reflect the effort you have put into your work?"; "Are your career development opportunities appropriate for the work you have completed?"; "Do your career development opportunities reflect what you have contributed to the organisation?"; "Are your career development opportunities justified, given your performance?"; "Have the opportunities you have received met your career development needs?". A Cronbach alpha score of 0.95 promoted the reliability and internal stability of this measure.

Employee perceptions of procedural justice were investigated using a seven item scale also developed by Colquitt (2001). Again, individuals were asked to respond, along a five point Likert scale (from a very little extent [1] to a very great extent [5]), to the following questions, "Are you able to express your views and feelings during those procedures used to decide your career development opportunities?"; "Do you have influence over the decisions arrived at by those procedures used to decide your career development opportunities?"; "Are these procedures applied consistently?"; "Are these procedures free of bias?"; "Are these procedures used to decide your career development opportunities based on accurate information?"; "Are you able to appeal the decision regarding your career development opportunities arrived at by these procedures?"; "Do these procedures used to decide your career development opportunities uphold ethical and moral standards?". A Cronbach alpha score of 0.93 provided strong support for the reliability and internal stability of this scale.

Employee perceptions of trust in management were measured using a 3-item scale developed by Brockner et al. (1997). Respondents were asked to evaluate along a 4point Likert scale the extent to which they agreed / disagreed with each of the following statements, "I can usually trust my career development supervisor to do what is good for me"; "Management can be trusted to make decisions that are also 
good for me"; "I trust the management to treat me fairly". A Cronbach alpha score of 0.87 promoted confidence in the reliability of the scale.

Careerist-orientations to work were measured using a 5-item scale developed by Chay and Aryee (1999), which in itself was a shortened version of an earlier scale developed by Feldman and Weitz (1991). Respondents were asked to evaluate, along a 5-point Likert scale, how much they agreed / disagreed with each of the following statements, "In terms of managing careers in organisations, it's each man/woman for himself/herself"; "In the final analysis, what's best for me in my career is not going to be consistent with what's in the organisation's best interests"; "My goals and my employer's goals probably will not be compatible"; "Loyalty to one's employer is unlikely to be rewarded"; "I don't think of myself as an, 'organisation man/ woman"”. A Cronbach alpha score of 0.68 was deemed to promote a moderate yet acceptable level of reliability. Indeed, the alpha reliability score reflected that reported in other previous studies using this scale (see Aryee and Chen, 2004).

Key control variables were also identified and measured. Previous research has highlighted the potential significant relationships that may exist between a number of demographic variables and career-related constructs (for examples, see Sullivan et al., 1998; Sutherland and Davidson, 1996; Wentling, 1996; Cascio, 1995). Data regarding minority ethnic status, gender, age, contract type (permanent/temporary), employment status (full/part time), job level, and length of service were all collected. The positive or negative psychological effects of either receiving or missing out on a desirable promotion would also be expected to have a significant impact on all the independent and dependent variables in the model. Whether or not each respondent had been promoted in the last two years was also therefore controlled for. Finally, employee perceptions of informational and interpersonal justice, regarding career development opportunities, were all also controlled for in this analysis. In line with the findings of previous research, it was predicted that these justice constructs may also be related to the outcome variables tested (see Colquitt et al., 2001; Bies and Moag, 1986).

\section{Findings}

All hypotheses were tested using enter method hierarchical regression analysis on SPSS version 11. The test for mediation (hypothesis 2) followed the method as outlined in Baron and Kenny (1986). Control variables were entered in the first step of the regression. Procedural justice was entered in the second step and its beta weight and significance recorded. In the third step trust in management was entered and again its beta weight and significance recorded. Accordingly, the drop in beta weight and significance of procedural justice were also recorded after trust in management was entered into the regression equation. The Sobel test was carried out to ascertain whether or not the drop in beta weight was statistically significant (see Baron and Kenny, 1986).

The test for moderation effects (hypothesis 3) followed the method described in Aiken and West (1991). The control variables were entered in the first step of the regression. In step 2 the main effects of distributive justice and trust in management were tested for. Finally, in step 3 a newly calculated distributive justice by trust interaction term was entered into the regression equation. To aid interpretation of interaction effects, levels of distributive justice and careerist orientation were plotted 
for plus or minus one standard deviation from the mean trust score (Aiken and West, 1991).

\section{Descriptive statistics}

For all multiple item measures (i.e. all the key independent and dependant variables outlined in the methodology) average scores across all items were calculated for each respondent; creating new 'averaged' variables. Means, standard deviations and intercorrelations were then calculated for all independent, dependent and control variables tested. A summary is presented in Table 1.

INSERT TABLE 1 ABOUT HERE

The demographic variables gender, contract type (part or full time), employment status (permanent or temporary), length of service and job level had no significant relationship with any of the main independent or dependent variables in the model. In other words, perceptions of distributive justice and procedural justice, trust and careerist orientation appear not to be a function of any of these variables. On the other hand, ethnicity is significantly related to a number of these key constructs. Due to the limited number of respondents in each of the minority ethnic groupings, two categories were created; white UK and non-white UK. It appears from these findings that white UK employees have far more positive experiences of career development opportunities and career management practices in FinanceCo. Non-white UK employees reported significantly more negative perceptions of distributive, procedural, interpersonal and informational justice and trust in management. Moreover, they also reported significantly higher levels of careerist orientation. The perceived barriers to career advancement and progression reported by ethnic minorities in previous studies (e.g. Schein and Davidson, 1993) appear to be confirmed again here.

The recent receipt (or not) of a promotion is also significantly associated with an individual's perceptions of justice, trust and careerist orientation. As one would perhaps expect, those who have recently received a promotion report significantly more positive perceptions of distributive justice and trust in management. Moreover, they are less likely to have developed more careerist orientations to work. In support of earlier research (e.g. Aryee and Chen, 2004); it seems that the receipt of valued career development opportunities has a positive effect on justice, trust and (reducing) careerism.

Table 1 also highlights the relatively high inter-correlations between the key independent variables in the study. This is to be expected given the close conceptual overlap between concepts such as trust and justice and is consistent with previous research (e.g. Aryee and Chen, 2004). That said, high inter-correlations between two (collinearity) or more (multicollinearity) variables can lead to singularity and increased standard error of the estimates, thus making accurate interpretation of the findings difficult (Tabachnick and Fidell, 2001; Hair et al., 1998). Most conservative 
writers suggest correlations of 0.70 and above as reflecting potentially 'problematic' levels of collinearity in a dataset (see Allison, 1999). An investigation of the descriptive statistics above (Table 1) highlights no correlation coefficients above 0.65 , comfortably within both sets of guidelines.

However, problems of multicollinearity are not necessarily observable in bi-variate correlations and thus an analysis of the variance inflation factors (VIF) associated within a regression model is therefore proposed as a more rigorous test (Tabachnick and Fidell, 2001; Hair et al., 1998; Morrow-Howell, 1994). VIFs evaluate the relationship between an independent variable and all other independent variables within a model, where higher VIF values equate to a higher standard error and thus lower precision of regression estimates (Fox, 1993). Again, the most conservative literature proposes VIF greater that 10 as evidence of potentially problematic multicollinearity (see, Hair et al., 1998). No VIF greater than 2.75 were found in this study. As the diagnostics gathered from both the correlation matrix and the VIF statistics provide strong support for a lack of problems with multicollinearity it is proposed that the relative stability and reliability of the tested model allows the results of the regression analyses presented within this study to be interpreted with confidence.

\section{Hypotheses 1 and 2}

Results for hypotheses 1 and 2 are summarised in table 2. As hypothesized, employee perceptions of procedural justice, regarding the procedures used to decide their career development opportunities were negatively related to their careerist orientations to work $(\beta=-.22, p<.01)$. Again, as predicted, employee perceptions of trust in management were also found to be negatively related to their careerist orientations ( $\beta$ $=-.23, p<.01)$ and to fully mediate the negative relationship between perceptions of procedural justice and careerist orientations to work. After entering trust into the regression equation the relationship between perceptions of procedural justice and careerist orientations became non-significant $(\beta=-.12, p>.10)$. Subsequent analysis of this drop in beta weight using the Sobel test confirmed this mediation as statistically significant $(z=-3.08, p<.001)$.

\section{INSERT TABLE 2 ABOUT HERE}

\section{Hypothesis 3}

As hypothesized, the relationship between an individual's trust in management and their careerist orientations to work was moderated by their perceptions of distributive justice regarding career development opportunities $(\beta=-.15, p<.01)$. However, in contrast to the proposed interaction effect, trust in management became more strongly and negatively associated with careerist orientations when distributive justice perceptions were high, rather than low (see Table 3 and Figure 2). 


\section{General discussion}

Trust mediates the negative relationship between an individual's perceptions of procedural justice, regarding the allocation of career development opportunities, and their careerist orientations to work. It appears that perceptions of procedural justice are strongly associated with careerist-orientations because procedural justice acts as an insight into, or heuristic for, the trustworthiness of management (see van den Bos et al., 2001; Brockner and Siegel, 1996). These findings confirm and strengthen those of Aryee and Chen (2004) within a new UK context, suggesting that trust plays a central role in a reciprocal relationship between employee and employer and the management of careers. When employers develop fair procedures (i.e. those that are objective, consistent, transparent, ethical, based on accurate data, and allows an individual a voice and a chance to challenge the outcome) for allocating career development opportunities employees are less likely to develop careerist orientations to work because their trust in management is maintained.

The present study, however, also extends the current literature by exploring the conditions under which this relationship between trust and careerist orientations may change. To this end, the negative relationship between trust in management and careerist orientations was indeed found to be moderated by an individual's perceptions of distributive justice. However, in contrast to the hypothesised moderation effect it was high (rather than low) levels of distributive justice that appeared to strengthen the relationship between trust and careerist orientations to work. It appears that trust matters more in terms of an individual's careerist orientations to work when they feel that they are receiving their fair share of career development opportunities. When employees feel that their career development opportunities are allocated inequitably (low distributive justice), it appears that trust in management is only very weakly associated with careerist orientations to work. These findings contradict RCT and those of earlier organizational justice research (see Brockner et al., 1997; Folger, 1987).

A closer inspection of previous research into these interaction effects may explain these findings. Although RCT proposed distributive justice as a moderator in this relationship most (if not all) previous studies in fact tested for an interaction effect between outcome favourability and trust (see Brockner et al., 1997; Brockner and Siegel, 1996; Brockner and Wiesenfeld, 1996). The close conceptual overlap between outcome favourability and distributive justice should not mask the key differences between them. While an individual may perceive that their career development opportunities are unfavourable they may, at the same time, also perceive them to be fair (Greenberg, 2001). As long as they feel that they have been treated in the same 
way as their colleagues, unfavourable career development opportunities may not necessarily be perceived as unfair. At the same time an individual may receive very favourable career development opportunities but view them as wholly unfair and unjustified (e.g. an unjustified promotion). The early research of Adam's (1965) identifies such situations of felt 'overpayment' inequity.

When their career development opportunities are viewed as simply unfavourable (i.e. they haven't received the career development opportunities they desired, but maybe no one else has either) an individual may initially give their employer the 'benefit of doubt' and seek further clarification about this decision; namely how trustworthy the system is that made it. If the employer is deemed trustworthy the unfavourable outcome is thus forgiven; at least in the short term (Folger, 1987). In contrast, when career development opportunities are viewed as unfair there may be no doubt as to their employer's mistreatment of them and thus no benefit in seeking any further information or clarification about the reasons for this decision.

The results do, however, suggest that when perceptions of distributive justice are high trust in management becomes more strongly related to careerist orientations. It may be that in certain situations high levels of distributive justice (as well as low) can also trigger sense-making in individuals. The current equitable distribution of career development opportunities, although positive, may not provide individuals with all the information required to make decisions about the nature of the employment relationship over the longer term. Such positive outcomes may, however, trigger further analysis into the nature of the relationship with their employer. In short, do I trust my employer to keep looking after my career development needs (as they are currently doing) over the longer term? Trust, therefore, becomes a more important predictor of careerist orientations under conditions of high distributive justice.

RCT is thus potentially extended. Sense-making may not simply be triggered by negative experiences (such as the receipt of unfair outcomes) as suggested by the early studies of Folger (1987) and others. In certain situations, the receipt of fair outcomes may also trigger such sense-making. This may, however, simply be a phenomenon associated with a career context and, in particular, the nature of careerist orientations to work. Much more research is needed within this, and different, contexts if we are to further extend our knowledge and understanding of RCT. Moreover, and echoing Greenberg (2001), if this research is to be useful the researchers who conduct it must continue to clarify the distinction between outcome favourability and distributive justice.

\section{Limitations and future research}

The contributions of this research should be viewed in light of a number of methodological limitations. Firstly, the single organization context reduces the generalizability of these findings to individuals not employed by this company. Despite confirming the findings of previous studies, future research needs to be carried out in different national and organizational contexts if we are to generate greater confidence in their generalizability.

Secondly, the self-report nature of the data raises the potential problems of common method bias in the findings. McClelland and Judd (1993) have, however, argued that 
these concerns do not apply to tests of moderation. Indeed, they have argued that common method bias may actually work against the detection of interaction effects, suppressing their statistical significance. The existence of a strong, statistically significant interaction effect within this study thus suggests that common method bias may not be a major problem.

Finally, the cross-sectional nature of this study does not allow the researchers to confirm the directions of causality inferred in the tested hypotheses. Future research using longitudinal designs is needed to better test the causal relationships proposed in the model. Such methodologies would also allow one to test for more complex multidirectional relationships. In short, careerist orientated individuals may have different views on what is fair and trustworthy in organisations. For example, where the culture of an organisation promotes careerist-orientations to work, individuals who buy in to that culture may feel unfairly treated by line managers who do not reward or recognise careerist attitudes and behaviours. Moreover, such line managers may be judged as rather untrustworthy.

Longitudinal research would also allow new insights into the relevance of this interaction effect throughout different stages of the career life cycle. It may be that perceptions of distributive justice, regarding their career development opportunities, are more important for an employee in the early stages of their career as they seek to gain as much valuable work experience as possible. Trust in management, on the other hand, may become more important to the same employee as he/she seeks more stability and security in the mid and late-stages of their career.

In addition to the future research directions implied by the limitations of this study it is also proposed that future work may wish to look more closely at different measures of trust. Within this research an overall, 'global or systemic' measure of trust in management is used. However, and particularly relevant to the study of careers where responsibility for career management is increasingly devolved to the line manager, 'management' may be more likely to refer to one's direct line manager. As a result it is a more interpersonal trust rather than systemic trust that may be pertinent (for a review see, Lewicki, Tomlinson and Gillespie, 2006). Future research should explore the relative impacts of systemic versus interpersonal trust on careerist orientation. It may be where trust in one's line manager is the key to careerist orientation that interpersonal justice and informational justice, rather than procedural justice, are more important predictors of trust (see Ambrose and Schminke, 2003).

\section{Practical implications}

While recognising these limitations, the practical implications of this study are substantial. Tyler and Degoey (1996) suggest that trust matters when an individual views the relationship with their employer as dependent and thus their position within this relationship as vulnerable to harm. The findings of this study provide good support for this proposition within the context of managing employee careers and career development.

Despite a growing literature espousing a shift towards self managed careers (for reviews, see Arnold, 2001; Newell, 1999), career development opportunities (e.g. promotions, attendance on training courses, secondments, access to mentors, overseas 
assignment [see Baruch and Peiperl, 2000]) are, on the whole, still agreed and allocated by senior decision-makers in management (Crawshaw, 2006). Employers must ensure therefore that their procedures and processes for deciding who receives these valued and finite resources uphold the principles of procedural justice. Moreover, that the agents responsible for implementing these procedures are also fully aware of these principles.

If not, trust is threatened and careerist orientations to work are more likely to emerge. If trust is lost, the findings of this study suggest that it is not easily rebuilt through the equitable distribution/allocation of career development opportunities. If, however, employers make a concerted effort to develop and maintain trusting relationships with their employees (through the implementation of fair career management procedures) this may further enhance the positive effects that the equitable distribution of career development opportunities may have on reducing careerist orientations in their employees. 


\section{References}

Adams, J. S. (1965), "Inequity in social exchange", in Berkowitz, L. (Ed), Advances in Experimental Social Psychology Vol. 2, Academic Press, New York, pp. 267-299.

Adamson, S. J. (1997), "Career as a vehicle for realization of self", Career Development International, Vol. 2 No. 5, pp. 245-253.

Aiken, L. S. and West, S. G. (1991), Multiple Regression: Testing and Interpreting Interactions, Sage, Newbury Park.

Allison, P. D. (1999), Multiple Regression: A Primer, Pine Forge, London.

Ambrose, M. L. and Schminke, M. (2003), "Organizational structure as a moderator of the relationship between procedural justice, interactional justice, perceived organizational support, and supervisory trust", Journal of Applied Psychology, Vol. 88 No. 2, pp. 295-305.

Arnold, J. (2001), "Careers and career management", in Anderson, N., Ones, D., Sinangil, H. and Viswesvaran, C. (Eds), Handbook of Industrial, Work and Organizational Psychology Vol. 2, Sage, London, pp. 115-132.

Arthur, M. B. and Rousseau, D. M. (1996), “A career lexicon for the $21^{\text {st }}$ century", Academy of Management Executive, Vol. 10 No. 4, pp. 28-39.

Arthur, M. B., Claman, P. H. and DeFillippi, R. J. (1995), "Intelligent enterprise, intelligent careers", Academy of Management Executive, Vol. 9 No. 4, pp. 7-22.

Aryee, S., Budhwar, P. S. and Chen, Z. X. (2002), "Trust as a mediator of the relationship between organizational justice and work outcomes: test of a social exchange model”, Journal of Organizational Behavior, Vol. 23 No. 3, pp. 267-285.

Aryee, S. and Chen, Z. X. (2004), "Countering the trend towards careerist orientation in the age of downsizing: test of a social exchange model", Journal of Business Research, Vol. 57 No. 4, pp. 321-328.

Baron, R. M. and Kenny, D. A. (1986), "The moderator-mediator variable distinction in social psychological research: Conceptual, strategic, and statistical considerations", Journal of Personality and Social Psychology, Vol. 51 No. 6, pp. 1173-1182.

Baruch, Y. and Peiperl, M. (2000), "Career management practices: An empirical survey and implications", Human Resource Management, Vol. 39 No. 4, pp. 347-366.

Bies, R. J. and Moag, J. F. (1986), "Interactional justice: Communication criteria of fairness", in Lewicki, R. J., Sheppard, B. H., and Bazerman, M. H. (Eds), Research on Negotiations in Organizations Vol. 1. JAI Press, Greenwich CT, pp. 43-55.

Brockner, J., Ackerman, G, and Fairchild, G. (2001), "When do elements of procedural fairness make a difference? A classification of moderating differences", in 
Greenberg, J. and Cropanzano, R. (Eds), Advances in Organizational Justice, Stanford Books, Stanford, CA, pp. 179-212.

Brockner, J. and Siegel, P. A. (1996), "Understanding the interaction between procedural and distributive justice: The role of trust", in Kramer, R. and Tyler, T. (Eds), Trust in Organizations: The Frontiers of Theory and Research, Sage, London, pp. 390-413.

Brockner, J., Siegel, P. A., Daly, J. P., Tyler, T., and Martin, C. (1997), "When trust matters: The moderating effect of outcome favourability", Administrative Science Quarterly, Vol. 42 No. 3, pp. 558-583.

Brockner, J. and Wiesenfeld, B. M. (1996), “An integrative framework for explaining reactions to decisions: Interactive effects of outcomes and procedures", Psychological Bulletin, Vol. 120 No. 2, pp. 189-208.

Cascio, W. F. (1995), Managing Human Resources: Productivity, Quality of Work Life, Profits (4 ${ }^{\text {th }}$ Edition), McGraw-Hill, London.

Chay, Y. W. and Aryee, S. (1999), "Potential moderating influence of career growth opportunities on careerist orientation and work attitudes: evidence of the protean career era in Singapore", Journal of Organizational Behavior, Vol. 20 No. 5, pp. 613623.

Colquitt, J. A. (2001), "On the dimensionality of organizational justice: A construct validation of a measure", Journal of Applied Psychology, Vol. 86 No. 3, pp. 386-400.

Colquitt, J. A., Conlon, D. E., Wesson, M. J., Porter, C. O. L. H., and Ng, K. Y. (2001), "Justice at the millennium: A meta-analytic review of 25 years of organizational justice research", Journal of Applied Psychology, Vol. 86 No. 3, pp. 425-445.

Crawshaw, J. R. (2006), "Justice source and justice content: evaluating the fairness of organisational career management practices", Human Resource Management Journal, Vol. 16 No. 1, pp. 98-120.

Cropanzano, R. and Greenberg, J. (1997), "Progress in organizational justice: Tunnelling through the maze", in Cooper, C. and Robertson, I. (Eds) International Review of Industrial and Organizational Psychology, Vol. 12, Wiley \& Sons Ltd, Chichester, pp. 317-372.

Feldman, D. C. (1985), "The new careerism: Origins, tenants, and consequences", The Industrial - Organizational Psychologist, Vol. 22 No. 1, pp. 39-44.

Feldman, D. C. and Weitz, B. A. (1991), "From the invisible hand to the gladhand: Understanding a careerist orientation to work", Human Resource Management, Vol. 30 No. 2, pp. 237-257.

Folger, R. J. (1987), "Reformulating the preconditions of resentment: A referent cognitions model”, in Masters, J. and Smith, W. (Eds), Social Comparison, Justice, 
and Relative Deprivation: Theoretical, Empirical, and Policy Perspectives. Erlbaum, Hillsdale, pp. 183-215.

Fox, J. (1993), "Regression diagnostics: an introduction", in Lewis-Beck, M. S. (Ed), Regression Analysis: International Handbook of Quantitative Applications in the Social Sciences (Vol. 2), Sage, London, pp. 245-334.

Greenberg, J. (2001), "Setting the justice agenda: Seven unanswered questions about "what, why, and how"”, Journal of Vocational Behavior, Vol. 58 No. 2, pp. 210-219.

Greenhaus, J. H., Callanan, G. A. and Godshalk, V. (2000), Career Management ( $^{\text {rd }}$ Edition), Draydon Press, Orlando, FL.

Hair, J. F. Jr., Anderson, R. E., Tatham, R. L. and Black, W. C. (1998), Multivariate Data Analysis (5 ${ }^{\text {th }}$ Edition: International), Prentice-Hall, London.

Hall, D. T. (1976), Careers in Organizations, Goodyear Publishing Company, California.

Harrison, R. (2002), Learning and Development ( $3^{\text {rd }}$ Edition), London, CIPD.

Herriot, P. and Pemberton, C. (1997), "Facilitating new deals", Human Resource Management Journal, Vol. 7 No. 1, pp. 45-56.

Herriot, P. and Pemberton, C. (1996), "Contracting careers", Human Relations, Vol. 49 No. 6, pp. 757-790.

Kanter, R. M. (1990), When Giants Learn To Dance: Mastering the challenge of strategy, management, and careers in the 90's, London, Unwin Paperbacks.

Leventhal, G. S. (1980), "What should be done with equity theory?" in Gregan, K. J., Greenberg, M. S. and Willis, R. H. (Eds), Social Exchange: Advances in Theory and Research, Plenum, New York, pp. 27-55.

Lewicki, R. J., Tomlinson, E. C. and Gillespie, N. (2006), "Models of interpersonal trust development: theoretical approaches, empirical evidence, and future directions", Journal of Management, Vol. 32 No. 6, pp. 991-1022.

Lind, E. A. and Tyler, T. R. (1988), The Social Psychology of Procedural Justice, Plenum, New York.

McClelland, G. H. and Judd, C. M. (1993), "Statistical difficulties of detecting interactions and moderator effects", Psychological Bulletin, Vol. 114 No. 2, pp. 376390.

Morrow-Howell, N. (1994), "The M Word: Multicollinearity in multiple regression", Social Work Research, Vol. 18 No. 4, pp. 247-251.

Newell, H. (1999), "Managing careers", in Bach, S. and Sisson, K. (Eds), Personnel Management. Blackwell, Oxford, pp. 218-240. 
Orpen, C. (1998), "Correlates of a careerist orientation to work", Psychological Reports, Vol. 82 No. 3, pp. 1248-1250.

Peiperl, M. and Baruch, Y. (1997), "Back to square zero: the post-corporate career", Organizational Dynamics, Vol. 25 No. 4, pp. 7-22.

Robinson, S. L. (1996), "Trust and breach of the psychological contract", Administrative Science Quarterly, Vol. 41 No. 4, pp. 574-599.

Robinson, S. L. and Morrison, E. W. (2000), "The development of psychological contract breach and violation: a longitudinal study", Journal of Organizational Behavior, Vol. 21 No. 5, pp. 525-546.

Rousseau, D. M. (1995), Psychological Contracts in Organizations, Sage, London.

Schien, V. and Davidson, M. J. (1993), "Think manager - think male: Managerial sex typing among UK business students", Management Development Review, Vol. 6 No. 3, pp. 24-28.

Stumpf, S., Colarelli, S., and Hartman, K. (1983), "Development of the Career Exploration Survey (CES)", Journal of Vocational Behavior, Vol. 22 No. 2, pp. 191226.

Sullivan, S., Carden, W. A. and Martin, D. F. (1998), "Careers in the next millennium: directions for future research", Human Resource Management Review, Vol. 8 No. 2, pp. 165-185.

Sutherland, V. J. and Davidson, M. J. (1996), "Managing diversity: Using an equal opportunities audit to maximise career potential and opportunities in a UK bank", European Journal of Work and Organizational Psychology, Vol. 5 No. 4, pp. 559582.

Tabachnick, B. G. and Fidell, L. S. (2001), Using Multivariate Statistics ( $3^{\text {rd }}$ Edition), HarperCollins, New York.

Tajfel, H. and Turner, J. C. (1979), “The social identity theory of inter-group behaviour", in Worchel, S. and Austin, L. (Eds), Psychology of Intergroup Relations, Nelson-Hall, Chicago, pp. 94-109.

Thibaut, J. and Walker, L. (1975), Procedural Justice: A Psychological Analysis, Erlbaum, Hillsdale.

Tyler, T. R. (1989), “The psychology of procedural justice: A test of the group-value model”, Journal of Personality and Social Psychology, Vol. 57 No. 5, pp. 830-838.

Tyler, T. R. and Degoey, P. (1996), “Trust in organizational authorities: the influence of motive attributions on willingness to accept decisions", in Kramer, R. and Tyler, T. (Eds), Trust in Organizations: The Frontiers of Theory and Research, Sage, London, pp. 331-356. 
Tyler, T. R. and Kramer, R. (1996), "Whither trust?" in Kramer, R. and Tyler, T. (Eds), Trust in Organizations: The Frontiers of Theory and Research, Sage, London, pp. 1-15.

Tyler, T. R., and Lind, E. A. (1992), “A relational model of authority in groups", in Zanna, M. (Ed), Advances in Experimental Social Psychology, Vol. 25, Academic Press, London, pp. 115-191.

van den Bos, K., Lind, E. A., and Wilke, H. A. M. (2001), "The psychology of procedural and distributive justice viewed from the perspective of fairness heuristics theory", in Cropanzano, R. (Ed), Justice in the Workplace: From Theory to Practice, Vol. 2, Lawrence Erlbaum Associates, London, pp. 49-66.

van den Bos, K., Wilke, H. A. M., and Lind, E. A. (1998), "When do we need procedural fairness? The role of trust in authority", Journal of Personality and Social Psychology, Vol. 75 No. 6, pp. 1449-1458.

Wentling, R. M. (1996), “A study of career development and aspirations of women in middle management", Human Resource Development Quarterly, Vol. 7 No. 3, pp. 253-270.

Wooten, K. C. and Cobb, A. T. (1999), "Career development and organizational justice: practice and research implications", Human Resource Development Quarterly, Vol. 10 No. 2, pp. 173-179. 
Table 1: Means, standard deviations and inter-correlations between model variables

\begin{tabular}{|c|c|c|c|c|c|c|c|c|c|c|c|c|c|c|c|}
\hline 1. Ethnicity & $\begin{array}{l}M \\
1.08\end{array}$ & $\begin{array}{l}S D \\
.28\end{array}$ & 1 & 2 & 3 & 4 & 5 & 6 & 7 & 8 & 9 & 10 & 11 & 12 & 13 \\
\hline 2. Gender & 1.68 & .47 & -.01 & & & & & & & & & & & & \\
\hline 3. Age & 34.54 & 9.93 & -.10 & .08 & & & & & & & & & & & \\
\hline 4. Part/Full time & 1.21 & .41 & -.10 & $.34 * *$ & $.21 * *$ & & & & & & & & & & \\
\hline 5. Temp/Perm & 1.08 & .11 & -.03 & .02 & -.04 & .08 & & & & & & & & & \\
\hline 6. Tenure & 8.83 & 6.73 & $-.22 * *$ & -.00 & $.55^{* *}$ & $.15^{* *}$ & $-.12 *$ & & & & & & & & \\
\hline 7. Job level & 1.46 & .56 & -.09 & $-.42 * *$ & .10 & $-.36 * *$ & .01 & $.23 * *$ & & & & & & & \\
\hline 8. Promotion & 1.78 & .41 & .06 & .01 & $.15^{* *}$ & $.15^{* *}$ & -.01 & .08 & $-.22 * *$ & & & & & & \\
\hline $\begin{array}{l}\text { 9. Interpersonal } \\
\text { justice }\end{array}$ & 4.39 & .96 & $-.15 * *$ & .01 & $.17 * *$ & $.14 * *$ & .07 & .10 & .07 & -.11 & & & & & \\
\hline $\begin{array}{l}\text { 10. Informational } \\
\text { justice }\end{array}$ & 3.68 & 1.20 & $-.15 * *$ & .09 & .10 & .11 & .08 & .03 & -.09 & $-.11 *$ & $.63 * *$ & & & & \\
\hline $\begin{array}{l}\text { 11. Distributive } \\
\text { justice }\end{array}$ & 2.89 & 1.24 & $-.13 *$ & .07 & .02 & -.06 & .04 & -.01 & .02 & $-.36 * *$ & $.34 * *$ & $.54 * *$ & & & \\
\hline $\begin{array}{l}\text { 12. Procedural } \\
\text { justice }\end{array}$ & 3.03 & 1.07 & $-.21 * *$ & .10 & $.14^{*}$ & .02 & .09 & .10 & -.06 & -.09 & $.45 * *$ & $.63 * *$ & $.65 * *$ & & \\
\hline 13. Trust & 2.81 & .63 & $-.22 * *$ & .08 & .09 & .09 & .11 & .03 & -.06 & $-.18 * *$ & $.51 * *$ & $.63 * *$ & $.54 * *$ & $.65 * *$ & \\
\hline $\begin{array}{l}\text { 14. Careerist } \\
\text { orientations }\end{array}$ & 2.90 & .63 & $.13^{*}$ & -.09 & -.09 & -.02 & -.10 & .01 & -.09 & $.12 *$ & $-.23 * *$ & $-.25 * *$ & $-.34 * *$ & $-.30 * *$ & $-.35 * *$ \\
\hline
\end{tabular}

Notes: $\mathrm{N}=325 ; * p<.05 * * p<.01$ 
Table 2: Results of test for mediation on careerist orientations (hypotheses 1 and 2)

\begin{tabular}{|c|c|c|c|}
\hline Step & Independent variables & $\begin{array}{c}\text { Standardized } \\
\text { Beta }(\beta)\end{array}$ & Change in $\mathrm{R}^{2}$ \\
\hline \multirow[t]{10}{*}{1} & Gender & $-.12^{*}$ & $.12 * * *$ \\
\hline & Age & -.10 & \\
\hline & Ethnicity & .09 & \\
\hline & Full/Part time & .01 & \\
\hline & Perm/Temp contracted & -.06 & \\
\hline & Tenure & .11 & \\
\hline & Job level & $-.14^{*}$ & \\
\hline & Promotion & .06 & \\
\hline & Interpersonal justice & -.08 & \\
\hline & Informational justice & $-.18 *$ & \\
\hline \multirow[t]{11}{*}{2} & Gender & -.11 & $.03 * *$ \\
\hline & Age & -.09 & \\
\hline & Ethnicity & .07 & \\
\hline & Full/Part time & -.02 & \\
\hline & Perm/Temp contracted & -.05 & \\
\hline & Tenure & .13 & \\
\hline & Job level & $-.16^{*}$ & \\
\hline & Promotion & .06 & \\
\hline & Interpersonal justice & -.06 & \\
\hline & Informational justice & -.06 & \\
\hline & Procedural justice & $-.22 * *$ & \\
\hline \multirow[t]{12}{*}{3} & Gender & -.11 & $.03 * *$ \\
\hline & Age & -.09 & \\
\hline & Ethnicity & .05 & \\
\hline & Full/Part time & -.01 & \\
\hline & Perm/Temp contracted & -.05 & \\
\hline & Tenure & .12 & \\
\hline & Job level & $-.17^{*}$ & \\
\hline & Promotion & .03 & \\
\hline & Interpersonal justice & -.03 & \\
\hline & Informational justice & .00 & \\
\hline & Procedural justice & -.12 & \\
\hline & Trust in management & $-.23 * *$ & \\
\hline
\end{tabular}

Notes: $N=325 ; * p<.05 * * p<.01 * * * p<.001$. 
Table 3: Results of test for moderation on careerist orientations (hypothesis 3)

\begin{tabular}{|c|c|c|c|}
\hline Step & Independent variables & $\begin{array}{l}\text { Standardized } \\
\text { Beta }(\beta)\end{array}$ & Change in $\mathrm{R}^{2}$ \\
\hline 1 & $\begin{array}{l}\text { Gender } \\
\text { Age } \\
\text { Ethnicity } \\
\text { Full/Part time } \\
\text { Perm/Temp contracted } \\
\text { Tenure } \\
\text { Job level } \\
\text { Promotion } \\
\text { Interpersonal justice } \\
\text { Informational justice } \\
\text { Procedural justice }\end{array}$ & $\begin{array}{l}-.11 \\
-.09 \\
.07 \\
-.02 \\
-.05 \\
.13 \\
-.16^{*} \\
.06 \\
-.06 \\
-.06^{*} \\
-.22^{* *}\end{array}$ & $.15 * * *$ \\
\hline 2 & $\begin{array}{l}\text { Gender } \\
\text { Age } \\
\text { Ethnicity } \\
\text { Full/Part time } \\
\text { Perm/Temp contracted } \\
\text { Tenure } \\
\text { Job level } \\
\text { Promotion } \\
\text { Interpersonal justice } \\
\text { Informational justice } \\
\text { Procedural justice } \\
\text { Distributive justice (DJ) } \\
\text { Trust in management }\end{array}$ & $\begin{array}{l}-.11 \\
-.09 \\
.05 \\
-.02 \\
-.04 \\
.13 \\
-.16^{*} \\
-.02 \\
-.04 \\
.05 \\
-.03 \\
-.21^{* *} \\
-.21^{* *}\end{array}$ & $.05 * *$ \\
\hline 3 & $\begin{array}{l}\text { Gender } \\
\text { Age } \\
\text { Ethnicity } \\
\text { Full/Part time } \\
\text { Perm/Temp contracted } \\
\text { Tenure } \\
\text { Job level } \\
\text { Promotion } \\
\text { Interpersonal justice } \\
\text { Informational justice } \\
\text { Procedural justice } \\
\text { Distributive justice (DJ) } \\
\text { Trust in management } \\
\text { DJ x Trust in management }\end{array}$ & $\begin{array}{l}-.11 \\
-.09 \\
.05 \\
-.02 \\
-.04 \\
.13 \\
-.16^{*} \\
-.04 \\
-.06 \\
.03 \\
-.02 \\
-.24^{* *} \\
-.18^{* *} \\
-.15^{* *}\end{array}$ & $.02 * *$ \\
\hline
\end{tabular}

Notes: $N=325 ; * p<.05 * * p<.01 * * * p<.001$. 
Figure 1: The hypothesized model

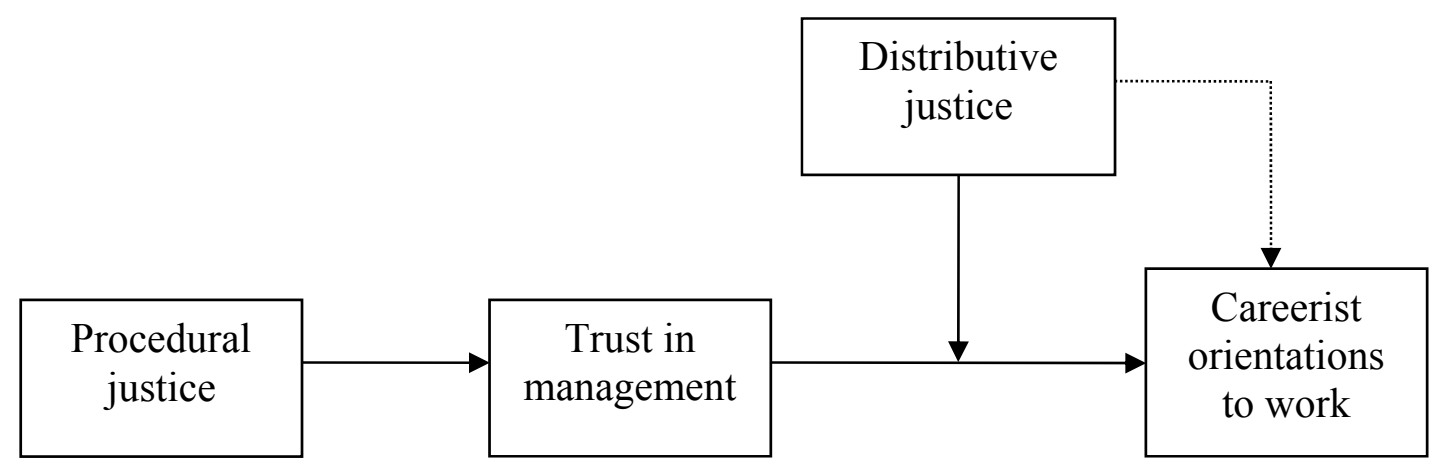

[based on Brockner, Ackerman \& Fairchild, 2001] 
Figure 2: Plotted distributive justice by trust interaction for careerist orientations

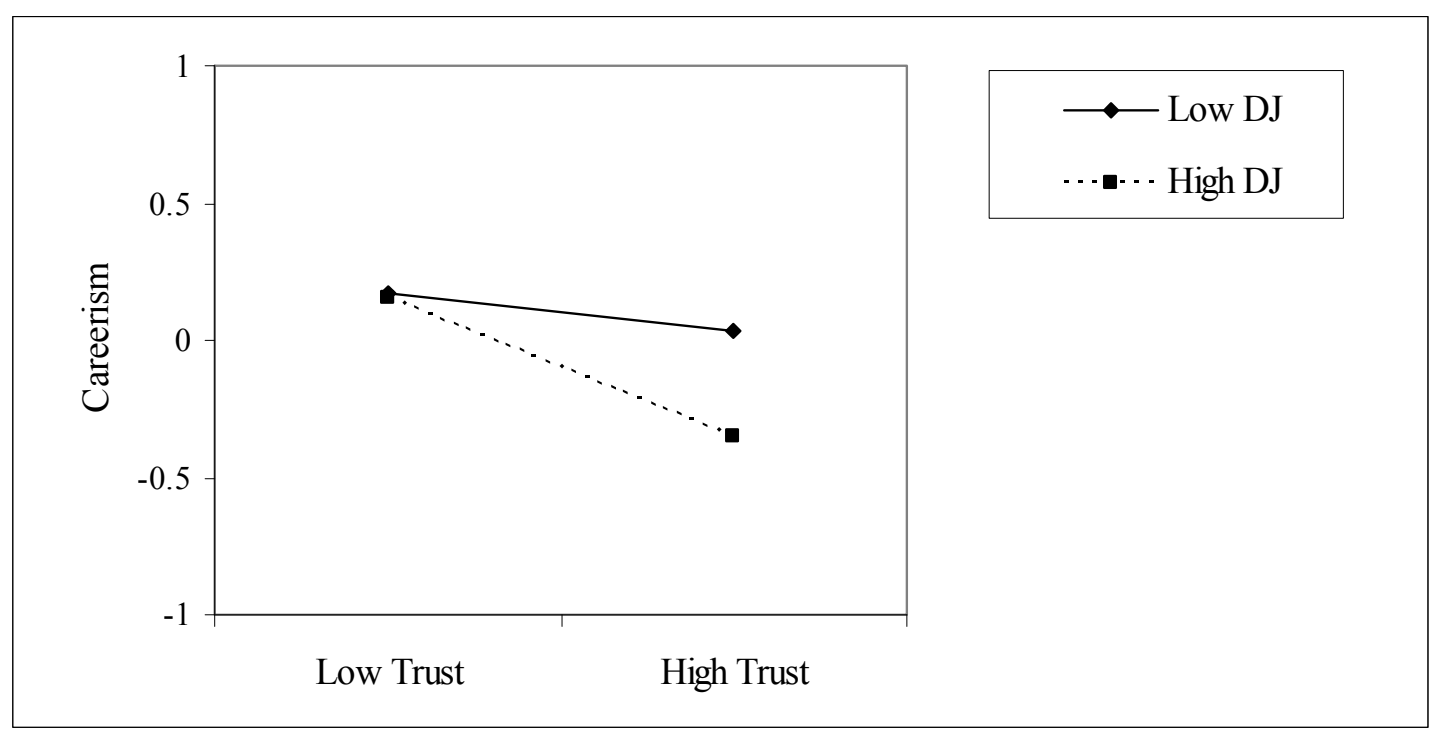

Note: $D J=$ Distributive justice 